\title{
Spatio-temporal Distribution of Entomophages in Phytocenoses of Anthropogenically Modified Landscape in the Forest-steppe of Western Siberia
}

\author{
Elena Yurievna Toropova, Lyubov Anatolievna Osintseva, \\ Elena Yurievna Marmuleva, Marina Pavlovna Selyuk \\ and Andrey Sergeevich Dyachenko
}

\author{
Doctor of Biological Sciences, Professor \\ Candidate of Agricultural Sciences, Associate Professor \\ Doctor of Biological Sciences, Professor \\ post-graduate student, student \\ The Novosibirsk State Agrarian University (NsSAU) \\ 160, Dobrolyubov Str., Novosibirsk, 630017, Russia \\ http://dx.doi.org/10.13005/bbra/2029
}

(Received: 23 December 2015; accepted: 01 February 2016)

\begin{abstract}
The research was aimed at identifying the characteristics of spatiotemporal distribution of entomophages in the herb and the aboveground layers in phytocenoses of agricultural landscape of the Northern forest-steppe of Western Siberia. Based on the analysis of the structure of entomocomplexes of phytocenoses with various types of flowering and frequency of anthropogenic successions (herbs dominated by Galéga orientalis, and adjacent phytocenoses of Vicia faba and Brassica napus), the similarity of the taxonomic composition of major entomophages and changes in the ratios in favor of phytophages in phytocenoses of cultivated crops has been shown. The close dependence of the number of insects on the hydrothermal conditions of vegetation conditions has been revealed. Biodiversity of entomocomplex in herbs has been veraciously higher, as compared to Vicia faba and Brassica napus, the total number of insects was maximum in the phytocenosis of fava beans due to the manifold increased domination of phytophages. The importance of preserving the sites with flowering plants as donors of natural entomophages has been proven. Their wide food chains ensure stabilization in the number of pests on annual crops that belong to different botanic families. The entomophagous complex underwent significant changes during migrations, carabids featured higher relative abundance in the agroecosystems of Vicia faba and Brassica napus, the level of dominance of entomophages in the herbs level remained at the level of phytocenosis of Galéga orientalis, ensuring natural regulation of phytophages population.
\end{abstract}

Key words: biodiversity, predominance, hydrothermal conditions, anthropogenic succession, phytophage, entomophage.

Modern enthomocomplexes of agricultural landscapes are characterized by dynamic homeostasis that has developed during microevolution of species under the influence of several natural and anthropogenic factors (Landis

\footnotetext{
* To whom all correspondence should be addressed.
}

et al., 2000). From the point of view of maintaining biological diversity of the enthomofauna and creating favorable conditions for activation of entomophages as an alternative method of suppressing the number of phytophagous insects, special attention should be paid to anthropogenic succession, trophic factors, and hydrothermal characteristics of the periods of invertebrates' activity (Barkalov, Burak, 2000). 
Useful insects, especially predators, may populate many biotopes (Douglas et al., 2000). Among entomophages, in phytocenoses of legumes, most important are syrphid flies, Coccinellidae and golden-eyed flies (Gorbachev et al., 2002; Demkin, 2008; Moraleva et al., 2013; Toropova, Murmuleva, 2014; 2015).

In the forest-steppe of Western Siberia, representatives of the 60 genera of syrphid flies have been detected, including 247 species that inhabit various biotopes (Barkalov, Sorokina, 2006). Studies of trophic relations of syrphid flies' larvae showed the presence of species with both wide food spectrum, and a limited number of victims (Gavrilyuk et al., 2008; Markova, Teofilova, 2011). A detailed study of food preferences of syrphid flies showed that specialization of syrphid flies larvae in relation to aphids has been mainly influenced by the kind of aphids, type of plant, and a complex of biotic and abiotic factors (Francis, 2005; Blaauw, Isaacs, 2012).

Complexes of coccinellidae species that are promising for field and horticultural crops pest control have been identified. Ecological features and coccinellidae trophic relations have been examined. Confinedness of large ladybirds such as Coccinella septempunctata has been noted to large colonies of aphids in the biotopes with small herbs, as well as shrubs and trees, in open fields, meadows, agricultural fields, suburban parks and gardens. The preferred winter quarters, for, e.g., C. septempunctata are open areas with covers (boulders, small mounds or hedges of herbs on the Southern side) (Turnocketall, 2003; Honek, Martinkova, 2005; Honeketall, 2007; Hodek, 2008). Levels of efficiency have been defined for coccinellidae on cereals, maize, peas, sunflower (Mokhrin, 2009), as well as the influence of abiotic and biotic (parasites, predators) factors on trophic specialization and activity of carnivorous ladybirds has been established (Kindlmann, et al., 2000; Abassi et all, 2001; Petersonet all, 2005; Miura, 2009; Riddick, Cottrell, 2009).

Specialized predators and parasitoids play a significant role in controlling the population of herbivorous thunder flies. Thus, Melilotus officinalis (L.) Pall. is inhabited by Aeolothrips intermedius (carnivorous) (Bagnall.), Frankliniella intonsa (Trybom) (heterophagous) and Thrips tabaci Lindeman (Conti, 2009). Aeolothrips intermedius and species of the Orius genus are used to control the population of phytophagous thunder flies (Fathi, 2008). Of parasitic insects, on the Hypera postica alfalfa weevil, Bathyplectes curculionis and Bathyplectes anurus develop (Gordh, Hendrickson, 1976; Bartell, Pass, 1978). For B. anurus, which is a parasitoid, synchronization with the development cycle of the host is of particular importance; when the peak of its number coincides with the peak number of phytonomus weevil larvae, infection is quite stable (Smilowith et al., 1972; Dowell, 1979). Otherwise, no number decrease is observed (Jordan, 1979). Microctonus aetioptoides Loan. parasitizes on imago thrips (Flessel, Niemczik, 1977). The infection rate is up to $88 \%$. (Van Drieshe, Górisko, 1979). Braconids of the Euphorus genus are noted as active entomophages of the alfalfa plant bug in Poland (Bilewicz-Pawinska, 1976, 1977). Although parasitic insects on Sitona weevils are less important in regulating their number, as compared to carnivorous, however, it has been found that infection with Microtonus aethiopoides during the year reduces the number of Sitona weevils twice (Aeschlimann, 1978).

Studying the influence of nectariferous plants on the activity and abundance of entomophages indicates steady increase in the number of many insect groups with increasing the area of flowering plants (Blaauw, Isaacs, 2012). For the forest steppe of Western Siberia it was found that permanent habitats and reproduction locations for many species of coccinellidae, neuropterans, carnivorous bugs, imago syrphid flies and parasitic hypnotherapy are shelterbelt plantings, herbs, legumes and gramineous herbs (Bokina, 2009).

Many entomophages penetrate into the fields from surrounding biotopes, such as wastelands, deposits, virgin plots, meadows and vegetation growing on the borders of forests and shelterbelts.

Studies of ecological and faunistic characteristics of carabids population revealed dominant groups that differ in periods of activity, reproduction, and trophic specialization, confinedness to natural and anthropogenically changed biotopes. In analyzing population of carabid fauna (the Calathus, Microlestes, Broscus, Pterostichus genera) of various biotopes, it has 
been noted that zoophages dominated on tillable lands (up to $90 \%$ of all carabids). Significant influence of anthropogenic and abiotic factors on carabids activity has been noted (Matalin, 1998; Grechanichenko, Guseva, 2000; Grechanichenko, 2001; Guseva, Koval, 2011; Lyubechansky, Bespalov, 2011).

On the territory of the mountainous part of the Northwestern Caucasus, 481 species of carabids belonging to 88 genera has been identified. 20 groups of Carabidae life forms have been found. By the ratio of trophic groups, zoophages (15 groups, 363 species, $75.5 \%$ ) predominate over mixed phytophages (5 groups, 118 species, 24.5 $\%)$. Studying the structure of dominance revealed that the most species-rich are the Carabus (13 species), Pterostichus (8), Harpalus (7), Trechus (4) Amara (4) genera. The dominants included Carabus prometheus, C. miroshnikovi, S. starckianus, C. reitteri, C. titan, C. circassicus, C. convallium, C. cumanus, C. decolor, C. koenigi, Pterostichus caucasicus, P. pseudopedius, P. fornicatus, and Thermoscelis insignis. In most cases, the dominating species were sedentary. High catch index in the transit biotopes is mainly due to migratory activity of carabids. Dominant Carabidae reduce or prevent the cross-species competition due to simultaneous implementation "a number of forms of ecological niches differentiation". Ecologically similar species have different life cycles, or greatly vary in size. Ecologically similar species that have similar life cycles are usually separated spatially (Bondarenko, Zamotailov, 2011).

Studying the species composition and biotopic distribution of herpetobiont coleopterans in the Nether-Polar Urals revealed 78 species grouped into four sets of beetles, distribution of which is primarily determined by the specifics of hydroedaphic factors in each type of biotopes, also associated with their altitude. Analysis of the degree of uniformity of insects' species composition by the Shannon index showed decline of this indicator from the meadow-forest to mountain-tundra habitat types (Zinoviev, Malozemov, 2002).

In Western Siberia, 154 species of carabids of 39 genera have been identified. More humid Pre-Altaian and the Barabyn forest-steppes are dominated by the Poecilus and Pterostiñhus genera, the more arid Kulunda steppe is dominated by the Harpalus and Amara genera. (Bespalov et al., 2010). On the Brassicáceae plants of the southern taiga zone of Western Siberia, 61 species of carabids (Coleoptera, Carabidae) of 25 genera have been detected. The basis of life forms spectra are zoophages. Repeated soil treatments during growing season contribute to significant predominance of carabids from the group of underlying soil stratobionts (43.1\%), mainly due to the P. melanarius (16.7 \%) and P. cupreus (14.5 $\%)$. The identified peculiarities of carabids trophic relations in Brassicáceae agrocenoses allow considering prevailing types as main abovesurface entomophages of several pests of cruciferous crops (Babenko, Nuzhnykh, 2002). Observations show that Pterostichus melanarius is characterized by a wide trophic niche, as compared to other carabids, which is the reason for their high abundance in many agricultural and natural ecosystems (Korolev, Brigadirenko, 2012).

Biodiversity and abundance of ground predators in agrocenoses depended on cultivated crops, and on corresponding agricultural methods that defined the characteristics of the microclimate, lighting conditions and soil compaction. In the fields with annual crops and fallow lands, complexes have formed of aboveground predators that prefer uncompacted soil and good light conditions. Soil cultivation resulted in increasing the richness in carabids species, and in increasing the abundance of the prevailing species (Guseva, Koval, 2011; Matalin, Budilov, 2003). Consideration of trophic relationships of the Pterostichus melanarius Illiger. carabids with representatives of soil mesofauna has shown that this species, having wide specialization, prefers zoophages weighing 8.0 to $31.9 \mathrm{mg}$, and sapro - and phytophages weighing over $128 \mathrm{mg}$, and redistributes the trophic load between prey depending on their population in a specific ecosystem. Studying communities of carabids in the forest-steppe in the South of Western Siberia at the $180 \mathrm{~m}$ continuous transect from the center of the forest outlier through the steppe and mesophytic meadows to a single standing tree showed that the population of carabids could be divided into groups inherent to open and arboreous biotopes. The population of open biotopes is more differentiated than the arboreous one; it is divided into groups of steppe 
and meadow habitats. Generalist species that do not prefer certain herbal biotopes have been identified (Lyubechansky, Bespalov, 2011).

Studying the influence of anthropogenic successions caused by fires on the population of soil arthropods in the Northern taiga of West Siberia (in the native pine forest not exposed to fire for at least 100 years, and in two stages of post-fire succession) showed that the macrofauna mainly contained carnivorous carabids from open spaces and mixed phytophages. In the old burned-out (about 50 years ago) forest, a mixed forest has formed with moss-lichenous cover, and in mesofauna the share of spiders increased, however, the population of carabids was most abundant and diverse (Mordkovich et al., 2006).

54 species of carabids (Coleoptera, Carabidae) have been identified in the West Siberian Northern taiga. The population of carabids in natural habitats was less abundant and numerous than in the anthropogenic ones. The biotopes with destroyed soil cover become habitats for carabids as soon as the next year, but this is not the fauna typical for the Northern taiga; it is mainly represented by widespread species. Such an unstable structure of the above-ground enthofauna persisted for at least 20 years, and only in a few decades later the composition of the mesofauna became similar to the natural one (Lyubechanskii, 2002).

Regularities of formation and functioning of entomocomplexes in phytocenoses with various biological diversity and the type of flowering of plants exposed to anthropogenic successions of various frequency require clarification, therefore, the research was aimed at identifying the characteristics of spatial and temporal distribution of entomophages in the herb layer and the aboveground layer by micro-zones of the agricultural landscape in the Northern forest steppe of Western Siberia.

\section{Methods}

The research was performed in 2008-2014 in the conditions of the Northern forest steppe of Western Siberia. Out of the seven years of research, 2 years were humid (hydrothermal index $>1$ ), and 5 years were arid (hydrothermal index $<1$ ). Humid years were 2009 and 2013, and arid years were 2008, 2010, 2011, 2012 and 2014.

The age-related dropping of Galega
(Galéga orientalis L.) was considered as a phytocenosis with minimal anthropogenic impact, which by the start of observation had been cultivated for 12 years in one place without soil mellowing. During the period of study, nectariferous plants of galega accounted for $80-90 \%$ of the projective cover. The rest of the phytocenosis was represented by herbs and ruderal flora: Setaria glauca, Echinochloacrus galli, Sonchus oleraceus, Amaranthus retroflexus, Bromus secalinus, Tripleurospermum inodorum, Elytrígia repens, Chenopodium album, Avena fatua, Poa annua, Convolvulus arvensis, Cirsium arvense, Taraxacum officinale, Plantago major, Urtíca urens. The area of a mixed herbs phytocenosis dominated by galega was 0.65 ha, from the West it was adjoined by a phytocenosis of fava beans (Vicia faba L.), at a small distance - by spring rape (Brassica napus L.), both with the area of 4-5 ha. To the North, nixed herbs bordered with a birch grove, where small fires occurred in the autumn every $4-5$ years. These fires resulted in absence of undergrowth and the ability of the birch grove to be heated. To the South, the galega phytocenosis bordered a maple grove (Acer negundo L.) with dense undergrowth and Pterídium aquilínum fern, which provided shade for the soil and ensured cool humid microclimate. The wood belt with poplars (Populus alba L.) and cereal grasses (Avena fatua, Poa annua, Dactylis glomerata, Phleum pratense, Bromus inermis, etc.) was adjacent to a fava beans phytocenosis.

Insects were counted dynamically every 7-10 days by the main development phases of nourishing plants, using conventional methods (Gorbachev et al., 2002). Carabids (genus Carabus, Pterostichus, and Calathus, etc.) were monitored by the method of soil traps. The traps were positioned evenly, so that both edges and the middle part of the phytocenoses may be inspected. In the herbs phytocenosis dominated by Galega orientalis L., carabids were counted in three microzones: the part of the phytocenosis next to the birch grove, the middle part of the plot, the micro-zone near the maple grove.

Sedentary insects (beet weevils, pea weevils of the Sitona genus) and their entomophages, small carabids (Bembidion R.) were counted on $0.25 \mathrm{~m}^{2}(0.5 \times 0.5)$ plots.

Small thermophilic insects that live on the 
surface of herbs, and their entomophages -the representatives of Coccinellidae, Braconidae, Aphidiidae, etc. families, were counted with the help of a net. A standard entomological net with 30 $\mathrm{cm}$ hoop, $60 \mathrm{~cm}$ deep bag and $1 \mathrm{~m}$ long arm was used. The net was moved in the same manner, along a quarter of a circle from the left to the right, and from the right to the left. After each movement, 1 step was made. The general direction in "mowing" with the net was windward, or lightward. One sample was 10 to 25 consequent sweeps of the net, depending on the activity and catching rate. Doing so, 10 or 25 steps were made in a straight line. After taking each sample, collected material was removed from the net and placed in a killing bottle. 10 samples have been taken, all of which consisted of 100 sweeps of the net.

The total number of bions was counted, and the average number per 50 or 100 sweeps of the net was determined; the bions were laid on mats to further definition of species.

Empirical data were ecologically (Magurran, 1992), and statistically analyzed in the STATISTICA software package.

\section{RESULTS}

Regardless of seasonal conditions, in the entomocomplexes of the agricultural landscape phytocenoses, expressed dominance of certain groups of insects has been detected. They are clearly confined to two tiers: herbs and the aboveground layer.

\section{Herb layer entomophages}

It has been established that in the period of vegetation, entomophages more frequently migrate from the stations with perennial crops with open type of flowering, where they had been wintering, and primarily fed, to the crops of annual plants (Pozharsky, Lysenko, 2012).

\section{Phytocenoses dominated by Galéga orientalis}

Entomophages, which are parasitoids on mixed herbs dominated by galega, were presented by Braconidae and Aphidiidae, Eulophidae, Scelionidae families, etc., their total number was 18 bions per 100 sweeps of the net, or $72 \%$ of the total number of entomophages. There were fewer representatives of the Coccinellidae, the Syrphidae, and the Chrysopida families; their number was $8 \%$, $12 \%$ and $8 \%$ of the total number of entomophages, respectively. Thus, in phytocenoses dominated by Galéga orientalis, same as clover (Toropova, Murmulev, 2014), parasites were much more numerous than predators. This is partly due to the fact that in the period of counting, females of parasitic insects received additional carbohydrate nutrition on openly flowering nectariferous plants, the predators to aphids ratio in the period of maximum abundance of aphids in 2011 was 1 to 23, i.e., it was effective (Demkin, 2008).

The dispersion analysis allowed to determine the share of influence of seasonal conditions and phases of Galéga orientalis development on the components on the main system of the herb layer triotroph in the studied phytocenosis: galega-aphids-entomophages (Table 1).

The data in the table show that the abundance of aphids was significantly influenced by the development phase of nutrition plants that determines the quality of the biotrophic nutrition for insects, while the abundance of aphid entomophages was mainly determined by seasonal conditions, which is related to the activity of galega flowering in clear and moderately warm weather.

\section{Phytocenosis of Vicia faba $L$}

In the role of Fabaceae phytocenosis with annual anthropogenic successions, we used a dropping of fava beans (Vicia faba) of the Siberian breed, directly bordering the galega phytocenosis.

Analysis of the taxonomic composition of fava beans entomocomplex showed its moderate similarity to galega - the average Jacquard coefficient per years was 0.61 . Lower (25\%) taxonomic diversity of the annual crops entomocomplex should be noted, mainly due to

Table 1. The share of influence of Galéga orientalis development phase and seasonal conditions on the abundance of the triotroph main system components: galega-aphids-entomophages, \%

\begin{tabular}{lcc}
\hline Insect taxa & \multicolumn{2}{c}{ Factor } \\
& $\begin{array}{c}\text { development } \\
\text { phase }\end{array}$ & $\begin{array}{c}\text { seasonal } \\
\text { conditions }\end{array}$ \\
\hline Aphididae & $77.3^{* *}$ & $12.1^{*}$ \\
Coccinellidae & 0 & $62.7^{* *}$ \\
Braconidae, Aphidiidae & 0 & $19.6^{*}$ \\
\hline
\end{tabular}

Note: * reliability of $95 \%$; ** reliability of $99 \%$ 
Table 2. Main types of coccinellidae on crops of fava beans

\begin{tabular}{|c|c|c|c|c|}
\hline \multirow[t]{3}{*}{ Species } & \multicolumn{4}{|c|}{ Total for the vegetation period by years } \\
\hline & \multicolumn{2}{|c|}{2008} & \multicolumn{2}{|c|}{2009} \\
\hline & abs. & $\%$ & abs. & $\%$ \\
\hline Propylaea quatuordecimpuctata L. & 21 & 28.8 & 34 & 64.2 \\
\hline Coccinella septempunctate L. & 12 & 16.4 & 10 & 18.7 \\
\hline Adonia variegate Goeze. & 22 & 30.1 & 7 & 13.3 \\
\hline Coccinella undecimpuctata L. & 18 & 24.7 & 2 & 3.8 \\
\hline
\end{tabular}

The least significant difference with the probability of 95\% equals to 6.1 bions.

Table 3. The share of influence of natural and anthropogenic factors on the abundance of the main components of the Vicia faba -aphids-entomophages triotroph, \% (2008-2014)

\begin{tabular}{lcccc}
\hline Insect & \multicolumn{3}{c}{ Factor } \\
\cline { 2 - 5 } & $\begin{array}{c}\text { development } \\
\text { phase }\end{array}$ & $\begin{array}{c}\text { seasonal } \\
\text { conditions }\end{array}$ & $\begin{array}{c}\text { fertilizers } \\
\text { the method of } \\
\text { sowing }\end{array}$ \\
\hline Aphididae & $40.2^{* *}$ & $17.4^{*}$ & 4.1 & 0 \\
Syrphid flies (Syrphidae) & $8.2^{*}$ & $41.3^{* *}$ & 0 & 0 \\
Coccinellidae & 2.6 & $62.7^{* *}$ & 0 & 0 \\
Golden-eyed flies (Chrysopidae) & $6.1^{*}$ & $39.9^{*}$ & & \\
Note: reliability of 95\%; ** reliability of 99\% & & & & \\
\hline
\end{tabular}

Analysis shows high dependency of the abundance of aphids on the

Table 1. The share of influence of Galéga orientalis development phase and seasonal conditions on the abundance of the triotroph main system components: galega-weevils-carabids, \%

\begin{tabular}{lcc}
\hline Insect taxa & \multicolumn{2}{c}{ Factor } \\
& $\begin{array}{c}\text { development } \\
\text { phase }\end{array}$ & $\begin{array}{c}\text { seasonal } \\
\text { conditions }\end{array}$ \\
\hline $\begin{array}{l}\text { Weevils (Sitona Germ.) } \\
\begin{array}{l}\text { Carabids (Carabus, } \\
\text { Pterostichus, Calathus) }\end{array}\end{array}$ & $16.3^{*}$ & $50.2^{* *}$ \\
\hline
\end{tabular}

Note: $*$ reliability of $95 \%$; $* *$ reliability of $99 \%$

hemipterans and coleopterans in the herbs.

The analysis of aphids' abundance dynamics showed that the most significant factors in pest control are natural entomophages that migrated after aphids from the galega phytocenosis. In crops of fava beans, the representatives of the following families of aphids' entomophages have been detected: coccinellidae, syrphid flies and golden-eyed flies.

Coccinellidae were the most numerous entomophages in the crops of fava beans throughout the entire growing season, averaging $83.7 \%$. Their appearance was detected before other groups of entomophages, and was synced with the beginning the budding and flowering phase of beans, i.e., almost simultaneously with the aphids. The number of entomophages in the phase of beans formation (in July) increased due to the appearance of larvae. 5 main Coccinellidae species was noted; their composition changed depending on the seasonal conditions. Table 2 shows the data from two contrasting years in terms of moisture: the arid 2008 (148 mm May through August) and the humid 2009 (228 mm).

Observations have shown that in arid years Adonia variegate and Propylaea quatuordecimpuctata prevailed. In humid years, Propylaea quatuordecimpuctata constituted more than half the population of ladybirds. Every year, Coccinella septempunctate $\mathrm{L}$. was also present on the crops at the level of $15-19 \%$. The highest dependence on the sum of precipitation during the growing season was shown by Coccinella undecimpuctata L.; its population increased in warm arid years up to 10 times and more, as 
compared to humid cool vegetation periods. Individual bions of Coccinella tredecimpunctata L. have been observed. With regard to cyclic polymorphism of coccinellidae, we found that larvae accounted for approximately $25 \%$ of the population.

Golden-eyed flies were second (12.2 percent) after coccinellidae, especially in warm arid years. In favorable conditions, larvae were about $50 \%$ of the population, while in cool and humid conditions, their share dropped on the average to
$25 \%$.

Syrphid flies were less frequent (up to $6.4 \%$ ) than other entomophages, and in the crops, mainly imagos were detected, especially in moderately moist warm years.

Dispersion analysis allowed to determine the influence of natural and anthropogenic environmental factors on the main representatives of this entomocomplex in the herb layer of fava beans (Table 3).

Analysis shows high dependency of the

Table 5. Abundance of major carabids taxa in herbs phytocenosis dominated by Galéga orientalis by micro-zones, bions per 4 traps, per year in 2012-2014

\begin{tabular}{|c|c|c|c|c|c|c|}
\hline \multirow[t]{2}{*}{ Genus, species } & \multicolumn{2}{|c|}{ Close to a birch grove } & \multicolumn{2}{|c|}{ The middle of the phytocenosis } & \multicolumn{2}{|c|}{ Close to a maple grove } \\
\hline & abs. & $\%$ & abs. & $\%$ & abs. & $\%$ \\
\hline Carabus: & 297 & 37.3 & 198 & 35.6 & 63 & 18.3 \\
\hline C. regalis & 257 & 32.3 & 176 & 31.8 & 53 & 15.4 \\
\hline C. adamsi & 40 & 5.0 & 21 & 3.8 & 8 & 2.3 \\
\hline C. sp. & 0 & 0 & 0 & 0 & 2 & 0.6 \\
\hline Pterostichus: & 490 & 61.6 & 345 & 62.4 & 279 & 81.1 \\
\hline Pt.cupreus & 192 & 24.1 & 74 & 13.4 & 15 & 4.4 \\
\hline Pt. melanarius & 24 & 3.0 & 23 & 4.2 & 11 & 3.2 \\
\hline Pt. versicolor & 4 & 0.5 & 3 & 0.5 & 0 & 0 \\
\hline Pt. lepidis & 4 & 0.5 & 3 & 0.5 & 19 & 5.5 \\
\hline Pt. nigrita & 192 & 24.1 & 170 & 30.7 & 92 & 26.7 \\
\hline Pt. oblongopanctatus & 21 & 2.6 & 23 & 4.2 & 127 & 36.9 \\
\hline Pt. macer & 44 & 5.5 & 37 & 6.7 & 11 & 3.2 \\
\hline Pt. niger & 0 & 0 & 2 & 0.4 & 4 & 1.2 \\
\hline Pt. sp. & 9 & 1.1 & 10 & 1.8 & 0 & 0 \\
\hline Chalatus: & 9 & 1.1 & 11 & 2 & 2 & 0.6 \\
\hline Ch. halensis & 1 & 0.1 & 3 & 0.5 & 0 & 0 \\
\hline Ch. melanocephalus & 7 & 0.9 & 6 & 1.1 & 2 & 0.6 \\
\hline Ch. sp. & 1 & 0.1 & 2 & 0.4 & 0 & 0 \\
\hline
\end{tabular}

Table 6. The taxonomic composition and population density (bions per trap) of large carabids in the fava beans phytocenosis, 2008-2014

\begin{tabular}{lccccc}
\hline \multirow{2}{*}{$\begin{array}{l}\text { Vicia faba phase of } \\
\text { development }\end{array}$} & Broscus & Pterostichus & Calatchus & Carabus & Calasoma \\
\cline { 2 - 5 } & 0.5 & 15.2 & 0 & 0 & 0 \\
\hline Beginning of branching & 0 & 11.6 & 0.3 & 0 & 0 \\
Branching & 0 & 8.0 & 0 & 0 & 0 \\
End of branching & 1.3 & 25.2 & 3.6 & 1.0 & 0.5 \\
Budding & 1.1 & 11.3 & 5.9 & 0 & 0 \\
Flowering & 4.0 & 22.5 & 20.5 & 7.0 & 0 \\
Fruit formation & 2.0 & 7.0 & 14.5 & 1.0 & 1.0 \\
End of fruit formation & 8.9 & 100.8 & 44.8 & 9.0 & 1.5 \\
Totals & 5.2 & 59.5 & 26.4 & 5.3 & 0.9 \\
\% & 0.2 & 2.0 & 0.5 & 0.7 & 0.1 \\
MSD ${ }_{05}$ by phenophases & & & & & \\
\hline
\end{tabular}


abundance of aphids on the phase of crop development, while the number and activity of entomophages was mainly determined by the weather conditions of the year, although the environmental preferences of individual taxa differed significantly, changing the ratio of species and genera.

The effectiveness criterion of a natural complex of entomophages populations was considered in terms of the total impact of all groups on the population of aphids: coccinellidae, syrphid flies, and golden-eyed flies. In our studies, the ratio in the entomophage to phytophage system, which is one of the indicators of entomophages' regulatory role throughout the entire growing season kept at an effective level (Demkin, 2008). The abundance of aphids was successfully regulated by entomophages.

\section{The Brassica napus L. phytocenosis}

In the role of phytocenosus of a plant with open-flowering and annual anthropogenic successions, sowing of spring rape (Brassica napus) of the SibNIIK 198 species was considered. Analysis of the taxonomic composition

Table 7. The share of influence of natural and anthropogenic factors on the abundance of the main components of the Vicia faba -weevils-carabids triotroph, \% (2008-2014)

Insect

Factor

Development phase Seasonal conditions Fertilizers The method of sowing

Weevils: Sitona lineatus

Sitona crinitus

Carabids of genus: Broscus

Pterostichus

Calathus

Bembidion

$37.8^{*}$
$21.0^{*}$
3.6
$6.3^{*}$
$8.3^{*}$
$77.8^{* *}$

$77.8 * *$
$41.1^{*}$
$65.8^{* *}$
$14.3^{*}$
40.6*
$10.1^{*}$
13.8*

$\begin{array}{cc}0 & 0 \\ 0 & 0 \\ 0 & 0 \\ 0 & 3.8 \\ 0 & 0 \\ 2.8 & 0\end{array}$

Note: * reliability of $95 \%$; ** reliability of $99 \%$

Table 8. Ecological analysis of grass stand entomocomplexes, bions per 100 sweeps

\begin{tabular}{lccc}
\hline Indicator & Galéga orientalis & Vicia faba & Brassica napus \\
\hline The average number of insect, bions per count & 59 & 55 & 86 \\
The maximum number of insects, bions per count & 130.7 & 423.4 & 188 \\
The total number of taxonomic groups of insects & 34 & 21 & 24 \\
The number of taxonomic groups of phytophages & 7 & 6 & 8 \\
The number of taxonomic groups of entomophages & 23 & 15 & 16 \\
The number of dominant species (up more than 50\% per count) & none & 3 & 2 \\
The number of constant species (occur in 50\% of counts) & 6.8 & 3.3 & 3 \\
The Margalef diversity index (DMg) & 3.1 & 1.1 & 1.6 \\
The Minnikh diversity index (DMn) & & & 4.0
\end{tabular}

Table 9. The maximum (per count) number and the Berger-Parker dominance index (d) of the main insect taxa in Fabaceae phytocenoses

\begin{tabular}{lcrrrr}
\hline \multirow{2}{*}{ Taxon } & \multicolumn{2}{c}{ The maximum number, bions per count } & & \multicolumn{2}{c}{$\mathrm{d}$} \\
\cline { 5 - 5 } & Galéga orientalis & Vicia faba & & Galéga orientalis & Vicia faba \\
\hline Sitona lineatus & 10 & 99 & 0.08 & 0.23 \\
Acyrthosiphon pisum & 35 & 217 & & 0.27 & 0.51 \\
Braconidae, Aphidiidae, etc. & 8 & 24 & 0.06 & 0.06 \\
Coccinellidae & 7 & 18 & 0.05 & 0.04 \\
Carabids of 6 genera*: & 4 & 54 & 0.03 & 0.13 \\
\hline
\end{tabular}


of the spring rape entomocomplex showed its weaker similarity to galega orientalis - the average Jacquard coefficient per years was 0.41 . The differences is due to the spread of specialized phytophages on the rape - genus Phyllotreta, Plutella xylostella L., Athalia colibri Christ., Brevicoryne brassicae L., genus Eurydema, family Pieridae, Meligethes aeneus F. Common to the three phytocenoses were entomophages of the Chrysopidae, the Syrphidae, the Coccinellidae, the Carabidae, the Braconidae, the Aphidiidae families, predatory bugs of the Nabidae, the Miridae and the Cantharidae families.

In the conditions of the forest-steppe in the $\mathrm{Ob}$ region, occurrence of entomophages on rape crops was observed in June. Before other entomophages, in the phase of stemming and the beginning of budding of rape plants, we observed emergence of coccinellidae. Later (in the flowering phase), imagos of syrphids and golden-eyed flies appeared, followed by their larvae. Out of coccinellidae, Coccinella septempunctate L., larvae and imagos of which most actively ate aphids, were most frequently observed on rape crops. Met the same Coccinella bipunctata, Coccinella septempunctata, Adonia variegate Goeze and Propylaea quatuordecimpuctata. Out of goldeneyed flies, aphids were eliminated by Chrysopa carnea and other species, mostly in the larva phase. Predatory syrphid flies (their number was higher than the number other predators groups) usually laid eggs on the leaves or on the stems of plants infested by aphids. The maximum number of syrphid larvae feeding on aphids on oilseed rape crops was observed in August. After reaching the last instar, the larvae pupated on the same plant. Later puparia were observed on oilseed rape crops; they had the appearance of comma-shaped drop. The mass emergence of syrphids imagos was noted in August. After emergence they flew away to feed on flowering plants. When the number ratio in the entomophages : aphids system was $1: 30$ (up to 80 ), rape crops were not processed with insecticides, which contributed to increasing profit with ecologically safe technology of crops cultivation.

The decrease in the number of cabbage aphids, most important were representatives of the Aphidiidae family. If infestation of the pest population in the second decade of July reached
$40 \%$ (with no more than $10 \%$ of plants infested), there was no need to use insecticides until the end of the season. On rape crops, we repeatedly observed a large number of aphid mummies infected with aphidiidae. In the laboratory, parasites emergence from them was observed. In small focal points in rape crops, development of white butterflies was noted. Their armyworms damaged leaves.

Therefore, studying the taxonomic structure of a community of entomophages on oilseed rape crops showed that during the period of the study, several species of coccinellidae, golden-eyed flies, and syrphids have been detected, and of parasitic insects, representatives of the Braconidae and Aphidiidae families were found. In addition, presence of adult hymenopterous parasites of white butterflies was detected on crops of rape, starting from the flowering phase. Rape provided carbohydrate food and the meeting place for parasitoids males and females. Towards the end of the oilseed rape flowering phase, infested armyworms of white butterflies were collected. The parasites from these armyworms were then incubated in the laboratory. Braconid larvae that had became nymphal in yellow silky cocoons collected into an uncompacted group close to the host, a dying armyworm of white butterfly, looked like yellow "pricks" of the cocoons. After emergence of parasites from the collective cocoon, neat holes were observed, through which the imagos of the braconids emerged. The parasites that emerged a week later (the average of 6 specimens) were dark colored and had fairly long antennae. Thus, presence of parasites on oilseed rape that infect armyworms of white butterflies has been proven.

\section{Entomophages of the above-surface layer}

Entomophages of the above-surface layer were represented by carabids, the taxonomic composition and the abundance of which depended on weather conditions of vegetation, the microclimate and the availability of plant food base.

\section{Phytocenoses dominated by Galéga orientalis}

Studying the taxonomic composition, the structure of the community and the peculiarities of seasonal dynamics of soil entomophagous Carabidae - in a phytocenosis dominated by Galéga orientalis showed that in the early 
vegetation season (in May) small ground beetles - Bohunice (g. Bembidion) were sporadically encountered; later, large species were highly abundant. The percentage of the representatives of large carabids from the galega phytocenosis, was as follows. Mostly, representatives of the Carabus and Pterostichus genera were caught (60.5 $\%)$. There were significantly fewer representatives of the Calathus genus caught. Single representatives of the Broscus and Calasoma genera were observed. Many burying beetles got into the traps throughout the entire season. Two peaks of carabids seasonal activity have been identified, associated with the emergence of the summer generation, abundance of insect pests and by the hydrothermal conditions, in the phases of Galéga orientalis full flowering and beginning of ripening (Arbab, McNeill, 2009). The peaks were shifted in time depending on the weather conditions for over 14 days per year (Table 4).

The number of carabids was mainly determined by the seasonal conditions, and weevils and carabids had similar environmental preferences: the maximum number of phytophages and carabids was observed in relatively humid years, when temperatures were close to the average data for several years.

Detailed analysis of the spatiotemporal distribution of carabids by micro-zones of phytocenosis showed significant difference both in the composition of the species and in the abundance of individual taxa (Table 5).

Large carabids were concentrated in the phytocenosis dominated by Galéga orientalis during the entire period of plant vegetation, where they found food in the form of pests: bugs, aphids, weevils, armyworms of butterflies and other insects feeding on various plant species. Analysis of the species composition and the abundance of large carabids shown in the table revealed their spatiotemporal preferences by the micro-zones of the phytocenosis. Accounting showed permanent presence of three genera of carabids in all traps during the growing season from May to September; the most numerous both in the species diversity and in the abundance was the Pterostichus genus. In the number of species, the leader was the central micro-zone, the lowest species diversity for all carabids genera was observed in the micro-zone next to the most shaded maple grove.
Throughout the entire vegetation season, significantly higher number of carabids of the most abundant genus Pterostichus close to the birch grove was observed, as compared to the microzone in the middle of the phytocenoses and close to the maple grove, the total being 1.4 and 1.7 times, respectively. This indicates that the total number of carabids decreased from the well-heated microzone next to the birch grove towards the more cool and humid micro-zone close to the maple thickets. Especially the micro-zone close to the grove was preferred by Pt. cupreus, the abundance of which was 12.8 times higher, as compared to the microzone near the maple thickets. On the opposite, Pt. oblongopanctatus was concentrated near the maple thicket, where its population was 5.8 times higher, as compared to the other micro-zones. The detected regularities are associated with the microclimate and trophic preferences of the species, and require further study.

Analysis of small and medium carabids revealed that carabids of the Bembidion genus (B. lampros, B. quadrimaculatum) were observed only in one micro-zone - near the birch grove. In the end of vegetation period, their number increased dramatically. This indicates that by the end of the growing season they migrated from annual legumes (in the fava beans field nearby) to the phytocenosis dominated by Galega.

Representatives of the Agonum and Amara genera were observed in all micro-zones. The former were caught only in two micro-zones (the goat shed near the grove and the middle of the field); starting in June, they also appeared near the maple thicket. Carabids of the Amara genus, which belong to mixed phytophages, were caught in significantly larger quantities in the middle of the field, especially in the beginning of the vegetation season. This can be explained by their nutritional features - they can feed on both animal and plant food.

\section{Phytocenosis of Vicia faba $L$}

In the phytocenosis of fava beans, carabids were the most important biotic factor that influenced the dynamics of pests' population weevil - Sitona lineatus L. and Sitona crinitus Hbst., 2-5 times dominated by S. lineatus.

Small carabids of the Bembidion genus were dominated by B. lampros and B. quadrimaculatum. Their initial emergence on crops 
occurred each year after the phenophase the beginning of branching. By the phenophase in the middle branching, sharp veracious $(\mathrm{P}<0.05)$ increase in the number of ground beetles was observed every year, according to the catching data - up to 4-14 bions per trap. Then the catch drastically reduced, almost to the zero, which indicated completion of the over-wintered generation of Bembidion imagos. After the phenophase of branching in fava beans, the number of carabid imagos of this genus significantly increased up to 7-8 bions per trap.

Thus, the data obtained about the dynamics of catches shows that carabids of the Bembidion genus in the local conditions had two quite expressed generations (the over-wintered and the summer ones), which developed in the period between the start of branching phenophase and the end of flowering. Abundance and dynamics of small carabids depended on the seasonal conditions, and was the highest in moderately warm and humid weather conditions in May to July, close to the average data for several years.

The taxonomic composition and density of populations of the large carabids caught in the phytocenosis of fava beans are shown in Table 6.

This data shows that in bean phytocenoses infested with weevils, significant richness in the species of predatory carabids was observed. The most abundant among large carabids were members of the Pterostichus genus that make up more than half of the entire complex (59\%), which, on the average over four years amounted to 100 bions per trap. Next, in descending order, representatives of the following genera came: Calatchus (26\%), 44 bions per trap, Carabus (5\%), 9 bions per trap, and Broscus (5\%) 8 bions per trap. The representatives of the Calasoma genus made up less than $1 \%$, or 1 bion per trap.

As our research has shown, the least number of weevils (4 bions per $\mathrm{m}^{2}$ ) and carabids (about 2 carabids per $\mathrm{m}^{2}$ ) was observed in the arid years; in these years, the optimal carabids to weevils ratio was established. (1:2,3). This is caused by the regulating effect of the lack of moisture, when entomophages are much more pressing, and fully control pests.

In cool and humid years, the maximum number of weevils ( 15 bions per $\mathrm{m}^{2}$ ) and carabids (about 5 bions per $\mathrm{m}^{2}$ ) was observed, as well as the maximum number of pest per one predator $(1: 3.4)$. As a result, the predator: the phytophage ratio was at the non-hazardous level, and it can be said that carabids successfully regulated the population of weevils in fava beans phytocenoses.

Dispersion analysis allowed to determine the influence of natural and anthropogenic environmental factors on the main representatives of the aboveground entomocomplex of fava beans (Table 7).

The table shows significant confinedness of phytophages (weevils) to the phases of host plant development. Entomophages, from the phases of the Vicia faba development most strongly influenced abundance of small carabids (Bembidion), whose preference for open warmed habitats is widely known (Guseva, Koval, 2011); while abundance of food in the form of eggs and larvae of weevils in the initial phases of plant development attracted over-wintered generation of the representatives of the genus. The number of all these dominant taxa, without exception, significantly depended on the hydrothermal conditions of the vegetation season, although the ecological preferences of individual taxa differed significantly, modifying the ratio of species and genera by years.

\section{The Brassica napus L. Phytocenosis}

During the period of the research, representatives of the following genera of the Carabidae family were found on spring rape in the above-surface layer: Pterostichus, Calathus, Bembidion, Calosoma, etc., the total of 7 taxa. They appeared on crops during the period of shoots formation, and were found throughout the entire vegetation period. Trophic relations of the identified taxa may include larvae and pupae of Pieris brassicae and Pieris rapae, as well as pupae of cruciferous flea beetles of the Phyllotreta genus (Nuzhnykh, 2004). The total number of carabids across years averaged 176 bions per trap per season. Representatives of the Pterostichus genus were mostly caught, on the average, $60.5 \%$. Second in terms of abundance were the members of the Calathus genus $-21.7 \%$. Next, in the descending order, representatives of the Bembidion, Broscus, Harpilus, Amara and Calosoma genera followed.

In moderately arid and humid years, representatives of 6-7 species of carabids were found on rape crops. The most numerous were 
representatives of Pterostichus, Pterostichus niger Schall in particular. The peak abundance of representatives of the Pterostichus genus was noted in early or mid July. The representatives of the other genera were much less numerous. Among the latter, most were the members of the Calathus Bonet. genus. They were mainly represented by two species: C. fuscipes and C. halensis. In very arid years, weather conditions caused a decrease in the number of separate groups of carabids. Most numerous still were Pterostichus (62,3\%), but, as compared to humid years, their number was 10$15 \%$ lower, due to the fact that they are quite moisture-loving. The Calathus carabids had a different tendency, which indicates their higher tolerance to heat and drought. The number of the members of this genus increased up to 4 times, and reached $32 \%$ of the total number. Occasionally, representatives of another carabids genus, Harpalus, appeared in the traps. Therefore, a stable complex of soil entomophages migrated annually in the phytocoenosis of spring rape; it reached its maximum number in the middle of the vegetation season (first and second decades of July), although the dominant taxa ratio changed under the influence of weather conditions of the vegetation period.

\section{DISCUSSION}

Comparative ecological analysis of herb layer entomocomplexes in the considered phytocenoses with various types of edificators flowering and levels of anthropogenic influence is shown in Table 8.

The data in the table shows that the type of flowering and annual anthropogenic successions had a significant impact on the biological diversity and on the abundance of insects. Comparison of Fabaceae phytocenoses shows that with almost equal average number of insects in sweeps in years, the phytocenosis of annual edificator is subject to much greater population fluctuations, and the difference in the maximum population detected in accounting for several years was 3.2 times, due to reproduction outbreaks of the most adapted species of phytophages. While in the Galéga orientalis phytocenosis there were no taxa with the dominance of $50 \%$ or more of the composition of the entomocomplex, in the beans phytocoenosis, there were three such species, which ensured rapid growth of the abundance of the insect community. In the phytocenosis of long-standing edificator, biological diversity was higher by $38 \%$, mainly due to entomophages and anthophilous pollinators, and permanent species were 2.8 times more numerous. The Margalef biological diversity index in the phytocenosis without anthropogenic successions was 2 times higher, and the Minnikh diversity index was 3 times higher, as compared to annual agrocenosis, which shows negative impact of anthropogenic pressure on the insect community. It should also be noted that in course of secondary annual successions, the free biotope was occupied by the species most adapted to prevailing conditions, whose dominance increased significantly (Table 9).

The data in the table shows that the dominance of pea aphids after migration from the Galéga orientalis phytocenosis to the Vicia faba agrocenosis increased almost twice, dominance of striped nodulating weevil increased 3 times, with the maximum number increasing 9.9 and 6.2 times, respectively. Out of entomophages, only carabids preferred warm and thinned fava beans phytocenosis; they found there abundant food in the form of eggs and larvae of weevils, and warm uncompacted soil. As a result, their dominance in the fava beans agrocenosis was 4.3 times higher, while the maximum observed population was 13.5 times higher! However, detailed analysis showed that the species diversity of carabids in the galega phytocenosis was 2-3 times higher. The aboveground entomophages have almost not changed the level of dominance in the compared phytocoenoses, since in different phases of development, they need both the carbohydrate (galega nectar) and the protein (aphids) nutrition.

The phytocenosis of spring rape that is subject to annual anthropogenic successions with the open type of edificator plant flowering, in many aspects occupied an intermediate position among the representatives of the Fabaceae family. During the period of observations, no significant abundance outbreaks have been detected even of the existing dominant specialized phytophages in the composition of the entomocomplex. The essential factor of phytophages control were entomophages, including parasitoids, which migrated from phytocenoses with open flowering 
perennial species, being attracted by the presence of phytophages and availability of carbohydrate nutrition during flowering of rape. The open type of oilseed rape flowering resulted in higher biological diversity of insects in the grass stand, as compared to fava beans; the phytophages and uncompacted soil also attracted to the actively migrating of carabids, whose number of taxa was significant, even compared to that in herbs.

\section{CONCLUSION}

Comparative analysis of Fabaceae (Galéga orientalis, Vicia faba) and Brassica napus phytocenoses entomocomplexes showed similarity of the taxonomic composition of the main entomophages, which indicates their annual migration from the phytocenoses of openly flowering perennial plants to the phytocenoses with annual anthropogenic successions. The seasonal population dynamics reflected a strong dependence of the number of phytophages and their entomophages on the hydrothermal conditions of vegetation, although the ecological preferences of individual taxa differed significantly, while the species to genera ratio changed over years. Biodiversity of the Galéga orientalis entomocomplex has been veraciously higher, as compared to the non-perennial crops phytocenoses, though the total number of insects was the highest in the phytocenosis of fava beans due to the manifold increased domination of phytophages. The entomophagous complex underwent significant changes during migrations, carabids featured a higher relative abundance in the agroecosystems of Vicia faba and Brassica napus, the level of dominance of entomophages in the herbs level remained at the level of phytocenosis of Galéga orientalis, ensuring natural regulation of phytophages population. In the whole, the research proves the importance of preserving the sites with flowering plants as donors of natural entomophages. Their wide food chains ensure stabilization in the number of pests on annual crops that belong to different botanic families.

\section{REFERENCES}

1. Babenko, A.S. and S.A. Nuzhnykh, 2002. Predatory aboveground coleopterans in planting cabbage. Plants Protection and Quarantine, 9: 39.

2. Barkalov, A.V. and V.A. Burak, 2000. The nature of anthophily in Cheilosia Mg. syrphid flies (Diptera, Syrphidae). Sib. Ecol. Journal, 4: 395408.

3. Barkalov, A.V. and V.S. Sorokina, 2006. Syrphid flies (Diptera, Syrphidae) of the forest-steppe of Western Siberia. Eurasian Enthomological Journal, Vol. 5, 3: 209-214.

4. Bespalov, A.N. and R.Y. Dudko, 2010. Lyubechansky I.I. Additions to the fauna of carabids (Coleoptera, Carabidae) of the Novosibirsk region: southern species spread to the North. Eurasian Enthomological Journal Vol. 9, 4: 625-628.

5. Bokina, I.G., 2009. Cereal aphids and their entomophages in the forest-steppe of Western Siberia. Novosibirsk: SUE RPAAA RAAS, pp: 182.

6. Bondarenko, A.S. and A.S. Zamotailov, 2011. Life cycles of some prevalent species of carabids (Coleoptera, Carabidae) in the uplands of Northwest Caucasus. The Volga Ecological Journal, 3: 256-265.

7. Gavrilyuk, A.V., V.S. Sorokina, T.A. Novgorodova et al., 2008. Revisiting trophic relationships of aphids (Homoptera, Aphididae) and aphidophagous syrphid flies (Diptera, Syrphidae) of the forest-steppe zone of Western Siberia. Eurasian Entomological Journal, 7(3): 236-242.

8. Gorbachev, I.V., V.V. Grinenko and Y.A Zachvatkin, 2002. Plants Protection from Pests. Moscow: Kolos, pp: 472.

9. Grechanichenko, T.E., 2001. Changing the structure of carabids population (Coleóptera, Carabidae) in the meadow steppe for the last decades. Ecology, 2: 132-136.

10. Grechanichenko, T.E. and N.A. Guseva, 2000 Population of carabids (Coleóptera, Carabidae) in the heterogeneous forest biotopes of the Central forest-steppe. Zoological Journal, Vol. 79, 5: 548-555.

11. Guseva, O.G. and A.G. Koval, 2011. Spatial distribution of carabids and staphylinidae (Coleoptera: Carabidae, Staphylinidae) in ôan agroecosystem. Agricultural Biology, 1: 118123.

12. Demkin, A.V., 2008. Agroecological aspects of protecting peas from a complex of harmful objects in the area of unstable moistening of the Stavropol territory, author's abstract from thesis of Candidate of Agricultural Sciences, Stavropol, pp: 23.

13. Zinoviev, E.V. and A.Y. Malozemov, 2002. 
Herpetobion coleopterans fauna in the neighborhood of the Neroyka Mount (the Nether-Polar Urals). The Siberian Ecological Journal, 6: 703-710.

14. Korolyov, O.V. and V.V. Brigadirenko, 2012. Trophic relation Pterostichus melanarius (Coleoptera, Carabidae) with dominant species of Invertibrates in forest ecosystems of steppe Dnieper region. Bulletin of the Dnepropetrovsk University, Vol. 20, 1: 48-54.

15. Lyubechansky, I.I., 2002. Population of carabids of the West Siberian Northern taiga and changes thereof in the process of sand pits overgrowing. The Siberian Ecological Journal, 6: 711-720.

16. Lyubechansky, I.I. and A.N. Bespalov, 2011. Spatial heterogeneity of carabids population (Coleoptera, Carabidae) in the gradient of forest and steppe: local level of consideration. The Siberian Ecological Journal, 4: 517-525

17. Marmuleva, E.Y., E.Y. Toropova, N.V. Davydova and S.A. Neustroeva, 2013. Environmental monitoring of fava beans enthomocomplex in the Northern forest-steppe of the Ob region. The Bulletin of the Altai State Agrarian University, 3(101): 51-56.

18. Matalin, A.V., 1998. Influence of weather conditions on migratory activity of carabids (Coleóptera, Carabidae) in the steppe zone. Bulletin of RAS. Biological Series, 5: 591- 601.

19. Matalin, A.V. and P.V. Budilov, 2003. Peculiarities of geographic variability of the sex-age structure of populations and the life cycle of Broscus cephalotes L. (Coleóptera, Carabidae) II. Zoological Journal, Vol. 82, 12: 1445-1453.

20. Mordkovich, V.G., O.G. Berezina, I.I. Lyubechansky, V.S. Andrievsky and I.I. Marchenko, 2006. Soil-dwelling arthropods of post-fire successions in the Northern taiga of Western Siberia. The Siberian Ecological Journal, 4: 429-437.

21. Mokhrin, A.A., 2009. The composition of species and ecologo-biocoenotic relations of coccinellidae (Coleoptera, Coccinellidae) in the agrobiocenoses of the Stavropol upland, author's abstract from thesis of Candidate of Biological Sciences, Saint-Petersburg, Pushkin, pp: 22.

22. Magarran, E., 1992. Ecological diversity and its measurement. Moscow: Mir, pp: 184.

23. Nuzhnykh, S.A., 2004. Coleopterous herpetobions (Carabidae, Staphylinidae) of the agrocenoses ùà cruciferous crops of the Southern taiga zone of Western Siberia, author's abstract from thesis of Candidate of Biological Sciences, Tomsk, pp: 15.

24. Pozharsky, S.M. and N.N. Lysenko, 2012. Phytophagous insects, fava beans diseases and measures for their control in the Orel region. Bulletin of the Orel State Agrarian University, Vol. 37, 4: 50-57.

25. Sorokin, O.D., 2009. Applied statistics with a computer. Krasnoobsk: Editing House of SUE RPA AA RAAS, pp: 222.

26. Toropova, E.Y. and E.Y. Murmuleva, 2014. Monitoring of the enthomofauna of red clover in the Northern forest-steppe of the Ob region. Bulletin of the KrasSAU, 5: 83-88.

27. Toropova, E.Y. and E.Y. Marmuleva, 2015. Biodiversity of carabids in the agrocenoses of spring-planted oilseed rape in the Northern forest-steppe of the $\mathrm{Ob}$ area. Modern Problems of Science and Education, 3. Date Views: 17.06.2015 http://www.science-education.ru/ 123-19752.

28. Abassi, S., M. Birkett, J. Petersson, J. Pickett, L. Wadhams and C. Woodcock, 2001. Response of the ladybird parasite Dinocampus coccinellae to toxic alkaloids from the seven-spot ladybird, Coccinella septempunctata. Journal of Chemical Ecology, 21: 33-43.

29. Aeschlimann, J.P., 1978. Heavy infestation of Sitona humeralis Stephens (Col., curc.) on lucerne in southern Morocco. Ann. Zool. Ecol. Anim., Vol. 10, 2: 221-225.

30. Arbab, A. and M.R. McNeill, 2009. Spatial distribution and sequential sampling plans for adult Sitona humeralis Stephens (Coleoptera: Curculionidae) in alfalfa. Journal of Asia-Pacific Entomology, Vol. 4, 7: 1-18.

31. Bartell, D.P. and B.C. Pass, 1978. Effects of Bathyplectes curculionis and Bathyplectes anurus [Hym.: Ichneumonidae] on the growth and development of Hypera postica [Col.: Curculionidae]. Entomophaga, September, Vol. 23, 3: 281-291.

32. Bilewicz-Pawinska, T., 1976. Wrogowie naturalni nicktorych polnych pluskwiakow (Miridae) e Polske. Roczn. Nauk. roln. Ser. E., Vol. 6, 1: 125-135.

33. Blaauw, B. and R. Isaacs, 2012. Larger wildflower plantings increase natural enemy density, diversity, and biological control of sentinel prey, without increasing herbivore density. Ecological Entomology, 11: 1-8.

34. Conti, B., 2009. Notes on the presence of Aeolothrips intermedius in northwestern Tuscany and on its development under laboratory conditions. Bulletin of Insectology, 62(1): 107-112.

35. Dowell, R.V., 1979. Effect of low host density on oviposition by larvae parasitoids of the alfalfa weevil / R.V. Dowell. J. New York Entomol. Society, Vol. 87, 1: 9-14. 
36. Fathi, S. et al., 2008. Interaction of Aeolothrips intermedius and Orius niger in controlling Thrips tabaci on potato. Int. J. Agri. Biol., 10: 521-525.

37. Flessel, J. and H. Niemczyk, 1977. Small wasp helps control alfalfa weevil in Ohio. Ohio Rep. Res. Developm. Vol. 62, 4: 64-65.

38. Francis, G., 2005. Syrphid aphidophagous predators in a food-web context. European Journal of Entomology, Vol. 102, 3: 325-333.

39. Gordh, G. and R. Hendrickson, 1976. Courtship Behavior In Bathyplectes anurus Hymenoptera Ichneumonidae. Entomological News, 87: 271274.

40. Honek, I. and A.Z. Martinkova, 2005. Long term changes of Coccinella septempunctata (Coleoptera: Coccinellidae) in the Czech Republic. European Journal of Entomology, 102: 443-448.

41. Honek, I., A.Z. Martinkova and S. Pekar, 2007. Aggregation characteristics of three species of Coccinellidae (Coleoptera) at hibernation sites. European Journal of Entomology, 104: 51-56.

42. Hodek, I. and J. Michaud, 2008. Why is Coccinella septempunctata so successful? (a point-of-view). European Journal of Entomology, Vol. 105, 1: 1-12.

43. Jordan, W.H., 1979. The weevil and the wasp. Natural History, Vol. 88, 10: 37-43.

44. Kindlmann, P., H. Yasuda, S. Sato and S. Katsuhro, 2000. Key life stages of two predatory ladybird species (Coleoptera: Coccinlellidae). European Journal of Entomology, 97: 495-499.
45. Landis, D.A., S.D. Wratten and G.M. Gurr, 2000. Habitat management to conserve natural enemies of arthropod pests in agriculture. Annu. Rev. Entomol., 45: 175-201.

46. Markova, E. and T. Teofilova, 2011. Syrphid communities (Syrphidae, Diptera) in basic types of agroecosystems in Karlovo valley (Bulgaria). Bulgarian Journal of Agricultural Science, 17(1): 49-54.

47. Miura, K., 2009. Parasitizing the ladybird beetle, Coccinella septempunctata L. (Coleoptera: Coccinellidae) from Japan. Entomological News, 121: 95-96.

48. Peterson, J., V. Ninkovic, R. Glinwood, M. Birkett and J. Pickett, 2005. Foraging in a complex environment-semiochemicals support searching behavior of the seven spot ladybird. European Journal of Entomology, 105: 365-370.

49. Riddick, E., T. Cottrell and K. Kidd, 2009. Natural enemies of the Coccinellidae: parasites, pathogens and parasitoids. Biological Control, 51: 306-312.

50. Turnock, W., I. Wise and F. Matheson, 2003. Abundance of some native coccinellines (Coleoptera: Coccinellidae) before and after the appearance of Coccinella septempunctata. The Canadian Entomologist, 135: 391-404.

51. Van Driesche, R.G. and G.G. Girisko, 1979. Field studies of Microctonus aethiopoides, a parasite of the adult alfalfa weevil, Hypera postica, in New York. Environ. Entomol., Vol. 8, 2: 238244. 